\title{
Presence of functional hyperpolarisation-activated cyclic nucleotide-gated channels in clonal alpha cell lines and rat islet alpha cells
}

\author{
Y. Zhang • N. Zhang • A. V. Gyulkhandanyan • E. Xu • \\ H. Y. Gaisano • M. B. Wheeler • Q. Wang
}

Received: 29 May 2008 / Accepted: 22 August 2008/ Published online: 11 October 2008

(C) Springer-Verlag 2008

\begin{abstract}
Aims/hypothesis The hyperpolarisation-activated cyclic nucleotide-gated ( $\mathrm{HCN})$ channels, discovered initially in cardiac and neuronal cells, mediate the inward pacemaker current $\left(I_{\mathrm{f}}\right.$ or $\left.I_{\mathrm{h}}\right)$. Recently, we have demonstrated the presence of HCN channels in pancreatic beta cells. Here, we aim to examine the presence and function of $\mathrm{HCN}$ channels in glucagon-secreting alpha cells.

Methods RT-PCR and immunocytochemistry were used to examine the presence of HCN channels in alpha cells. Whole-cell patch-clamp, calcium imaging and glucagon secretion experiments were performed to explore the function of HCN channels in alpha cells.

Results HCN transcripts and proteins were detected in alpha-TC6 cells and dispersed rat alpha cells. Patch-clamp recording showed hyperpolarisation-activated currents in alpha-TC6 cells, which could be blocked by HCN channel inhibitor ZD7288. Glucagon secretion RIA studies demonstrated that at both low and high glucose concentrations
\end{abstract}

Q. Wang and M. Wheeler contributed equally to this study.

Y. Zhang • A. V. Gyulkhandanyan • E. Xu • H. Y. Gaisano •

M. B. Wheeler $\cdot$ Q. Wang

Departments of Physiology and Medicine, University of Toronto,

Toronto, ON, Canada

Y. Zhang $\cdot$ N. Zhang $\cdot$ E. Xu $\cdot$ Q. Wang

Division of Endocrinology and Metabolism,

Department of Medicine, Li Ka-Shing Knowledge Institute,

St Michael's Hospital,

Toronto, ON, Canada

Q. Wang $(\bowtie)$

St Michael's Hospital,

Room 7005, Queen Wing, 30 Bond Street,

Toronto, ON, Canada M5B 1W8

e-mail: qinghua.wang@utoronto.ca
(2 and $20 \mathrm{mmol} / \mathrm{l}$ ), ZD7288 significantly enhanced glucagon secretion in alpha-TC6 and IN-R1-G9 cell lines. Conversely, activation of $\mathrm{HCN}$ channels by lamotrigine significantly suppressed glucagon secretion at the low glucose concentration. Calcium imaging studies showed that blockade of HCN channels by ZD7288 significantly increased intracellular calcium in alpha-TC6 cells, while lamotrigine or the $\mathrm{Na}^{+}$channel blocker tetrodotoxin suppressed the effect of ZD7288 on intracellular calcium. Furthermore, we found the HCN channel inhibitors ZD7288 and cilobradine both significantly increased glucagon secretion from rat islets. Conclusions/interpretation These results suggest a potential role for $\mathrm{HCN}$ channels in regulation of glucagon secretion via modulating $\mathrm{Ca}^{2+}$ and $\mathrm{Na}^{+}$channel activities.

Keywords Alpha cell · Glucagon secretion · HCN channel · Pancreatic islet

\section{Abbreviations}

$\left[\mathrm{Ca}^{2+}\right]_{\mathrm{i}}$

GABA

HCN channel

$I / V$

$\mathrm{K}_{\text {ATP }}$ channel

KRB

TTX

$V_{1 / 2}$ intracellular $\mathrm{Ca}^{2+}$ concentration $\gamma$-aminobutyric acid hyperpolarisation-activated cyclic nucleotide-gated channel current-voltage relationship ATP-sensitive $\mathrm{K}^{+}$channel Krebs-Ringer bicarbonate tetrodotoxin membrane potential of half-maximal activation

\section{Introduction}

Homeostasis of blood glucose is controlled mainly by insulin and its opposing hormone glucagon. High blood 
glucose stimulates insulin secretion from pancreatic beta cells but suppresses glucagon secretion from pancreatic alpha cells. It is known that glucose-induced insulin secretion occurs via the glucose-sensing pathway, which involves the closure of ATP-sensitive $\mathrm{K}^{+}$channels $\left(\mathrm{K}_{\text {АTP }}\right.$ channels) with resultant membrane depolarisation, and the activation of voltage-gated L-type $\mathrm{Ca}^{2+}$ channels and subsequent $\mathrm{Ca}^{2+}$-dependent exocytosis of insulin from the beta cells [1]. However, the mechanism regulating glucagon secretion remains relatively unclear.

Insulin is known as a physiological suppressor of glucagon secretion [2-4]. There is evidence that substances including $\mathrm{Zn}^{2+}$ [5], $\gamma$-aminobutyric acid (GABA) [6-8] released from beta cells and somatostatin secreted from neighbouring delta cells [9] have important roles in the modulation of glucagon secretion. Thus, it has been proposed that glucose may induce suppression of glucagon release by indirect actions via a paracrine mechanism. Recent studies have suggested that the mechanisms underlying glucagon regulation may also involve a direct effect of glucose on alpha cell stimulus-secretion coupling, in which ion channels play an important role $[10,11]$.

It is well established that electrical activity in beta cells mainly depends on activity of $\mathrm{K}_{\text {ATP }}$ channels, L-type $\mathrm{Ca}^{2+}$ channels and delayed rectifying $\mathrm{K}^{+}$channels $[1,12,13]$. Unlike in beta cells, studies using rodent, human and guinea pig pancreatic alpha cells have suggested that more $\mathrm{Ca}^{2+}$ channel subfamilies, i.e. $\mathrm{T}$ - and $\mathrm{N}$-type $\mathrm{Ca}^{2+}$ channels and tetrodotoxin (TTX)-sensitive $\mathrm{Na}^{+}$channels are also important in the regulation of alpha cell electrical activity [11, 13-17]. One important feature of these alpha cell ion channels is their voltage-dependent inactivation when the cell membrane is depolarised [14, 17, 18]. Accordingly, a model for glucagon secretion has been proposed that highlights the important roles of ion channels in regulating glucagon secretion. In this model, action potential firing (and glucagon secretion) in alpha cells occurs only within a narrow window of the membrane potentials that allows opening of voltage-dependent $\mathrm{Na}^{+}$channels and T- or $\mathrm{N}$-type $\mathrm{Ca}^{2+}$ channels. At low glucose conditions, intermediate $\mathrm{K}_{\mathrm{ATP}}$ channel activity maintains alpha cell membrane potential at the activation threshold for $\mathrm{Na}^{+}$and $\mathrm{T}-$ and N-type $\mathrm{Ca}^{2+}$ channels, causing a rise in cytosolic $\mathrm{Ca}^{2+}$ concentration and triggering glucagon secretion $[10,11$, $13,14,16]$. However, when the membrane potential is depolarised (e.g. $\mathrm{K}_{\text {ATP }}$ channels close under high glucose conditions), this will voltage-inactivate the $\mathrm{Na}^{+}$and T- and $\mathrm{N}$-type $\mathrm{Ca}^{2+}$ channels, resulting in the cessation of action potential firing and suppression of glucagon secretion [10, $11,14,18]$. On the other hand, when the alpha cell membrane potential is excessively hyperpolarised (e.g. a large fraction of $\mathrm{K}_{\mathrm{ATP}}$ channels opening under diazoxide treatment), the $\mathrm{Na}^{+}$and $\mathrm{Ca}^{2+}$ channels will switch to a closed state, thus silencing the alpha cell regenerative electrical activity and inhibiting glucagon secretion [11]. These studies suggest that the coordination of different ion channels in alpha cells composes the fine regulatory mechanism that controls glucagon secretion. Here, we report that a new ion channel, the hyperpolarisationactivated cyclic nucleotide-gated $(\mathrm{HCN})$ channel, may play a role in the control of glucagon secretion in alpha cells.

HCN channels are members of a superfamily of voltagegated cation channels that are permeable to both $\mathrm{Na}^{+}$and $\mathrm{K}^{+}$ions and produce a slowly activating inward current. Unlike most voltage-dependent channels, HCN channels are activated by membrane hyperpolarisation. HCN channels were initially identified in cardiac and neuronal cells, and play a key role in regulation of heart rate and spontaneous electrical activity of neurons [19-22]. To date, four mammalian $\mathrm{HCN}$ isoforms (HCN1-4) have been cloned. Studies on isoform distribution showed that while HCN3 is found primarily in neurons [23, 24], the other three isoforms are found in heart and brain [23, 25]. The HCN transcripts are also detected in several other organs, including skeletal muscle and lung [24]. Recently, we had discovered that $\mathrm{HCN}$ channels are present in pancreatic beta cells [26]. In the present study, we examined the presence and function of $\mathrm{HCN}$ channels in pancreatic alpha cells.

\section{Methods}

Islet isolation and cell culture Pancreatic islets were isolated from 250-350 g male Wistar rats (Charles River, Quebec, QC, Canada) by collagenase digestion and separated by density gradient centrifugation, as described previously [26]. Intact islets were cultured in RPMI 1640 medium containing $11.1 \mathrm{mmol} / \mathrm{l}$ glucose supplemented with $10 \%$ (vol./vol.) fetal bovine serum, $10 \mathrm{mmol} / \mathrm{l} \mathrm{HEPES}$, $100 \mathrm{U} / \mathrm{ml}$ penicillin and $100 \mu \mathrm{g} / \mathrm{ml}$ streptomycin for $24 \mathrm{~h}$ before experiments. Alpha-TC6 cells (a kind gift from Y. Moriyama, Okayama University, Okayama, Japan) and IN-R1-G9 cells (a kind gift from P. Brubaker, University of Toronto, Canada) were maintained in DMEM (Gibco Invitrogen, Burlington, ON, Canada), containing fetal bovine serum ( $10 \%$ vol./vol.), $100 \mathrm{U} / \mathrm{ml}$ penicillin $\mathrm{G}$ sodium, $100 \mu \mathrm{g} / \mathrm{ml}$ streptomycin sulphate and $55 \mathrm{mg} / 500 \mathrm{ml}$ sodium pyruvate, at $37^{\circ} \mathrm{C}$ in an atmosphere of humidified air (95\%) and $\mathrm{CO}_{2}(5 \%)$. In studies involving serum starvation, serum was replaced by $0.1 \%$ (wt/vol.) BSA in DMEM and incubated with the cells for $1 \mathrm{~h}$. All animal procedures were approved by the Animal Care Committees at St Michael's Hospital and the University of Toronto.

RT-PCR Total cellular RNA was extracted from cells using Trizol (Invitrogen) following the manufacturer's instruc- 
tions. HCN mRNA transcripts were amplified using a onestep RT-PCR kit (Qiagen, Valencia, CA, USA). Briefly, $100 \mathrm{ng}$ total RNA was used in $25 \mu$ l one-step RT-PCR reactions containing $0.4 \mathrm{mmol} / 1 \mathrm{dNTPs}$ and $0.6 \mu \mathrm{mol} / 1$ of each primer. Water was used to replace the template for the negative control. PCR conditions were $50^{\circ} \mathrm{C}$ for $30 \mathrm{~min}$, and $95^{\circ} \mathrm{C}$ for $15 \mathrm{~min}$, and 35 cycles of $94^{\circ} \mathrm{C}$ for $30 \mathrm{~s}, 60^{\circ} \mathrm{C}$ for $30 \mathrm{~s}$, and $72^{\circ} \mathrm{C}$ for $1 \mathrm{~min}$ followed by a $10 \mathrm{~min}$ extension at $72^{\circ} \mathrm{C}$. The products were separated on a $1 \%$ (wt/vol.) agarose gel and visualised with ethidium bromide. The HCN genespecific primers used were as follows: HCN1, sense $5^{\prime}$ CAGCATGTCTGACCTCTGGA-3', antisense 5'-TATCTT CTGGCGCATGTCAG-3'; HCN2, sense 5'-ATGTCCTTC CACAAACTGCC-3', antisense 5'-TCCCCTCTCGGATGA TGTA-3'; HCN3, sense 5'-GTGGAAATCGAGCAGGA GAG-3', antisense 5'-GCAGGAAGAAAGTGTCCGAG-3'; and HCN4, sense 5'-GCGTTTTGAGGTCTTTCAGC-3', antisense 5'-TCATGGGATACTCCTCCAGC-3'.

Immunostaining Alpha-TC6 cells and rat islets were dualstained for glucagon and $\mathrm{HCN}$ channels using a protocol similar to one used in a previous report [27]. In brief, cells or islets grown on coverslips were fixed with paraformaldehyde $(3.7 \%$ [wt $/ \mathrm{vol}$.] in PBS) and permeabilised with $0.2 \%$ (vol./vol.) Triton X-100. After blocking with PBS containing $5 \%$ (vol./vol.) goat serum and $1 \%(\mathrm{wt} / \mathrm{vol}$.) BSA for $60 \mathrm{~min}$, an antibody to HCN2 (1:100; Alamone Labs, Jerusalem, Israel) was added and left overnight at $4^{\circ} \mathrm{C}$. After washing out excessive primary antibodies, cells or islets were incubated with FITC-conjugated goat anti-rabbit IgG (1:500; Jackson Immuno Research Laboratories, West Grove, PA, USA) for $30 \mathrm{~min}$. The second staining was performed using an antibody to glucagon (1:500; Dako, Carpinteria, CA, USA) and a Cy3-conjugated secondary antibody (1:500; Jackson Immuno Research) as described above. The images were visualised using a Leica TCS 4D laser confocal fluorescence microscope (Leica, TCS-NT, Microsystems, Bensheim, Germany).

Electrophysiology Cells were patch-clamped in the conventional whole-cell configuration at room temperature. The measurements were performed using an EPC-9 amplifier and PULSE software from HEKA Electronik (Lambrecht, Germany). Patch pipettes were pulled from $1.5 \mathrm{~mm}$ thin-walled borosilicate glass tubes using a twostage Narishige micropipette puller (Tokyo, Japan) and had typical resistances of 3-6 M $\Omega$ when fire polished and filled with an intracellular solution containing $(\mathrm{mmol} / \mathrm{l}) 130 \mathrm{KCl}$; $10 \mathrm{NaCl} ; 0.5 \mathrm{MgCl}_{2} ; 1$ EGTA; 5 HEPES; 5 MgATP; $\mathrm{pH} 7.3$ with $\mathrm{KOH}$. Extracellular solutions contained (mmol/l) 110 $\mathrm{NaCl} ; 0.5 \mathrm{MgCl}_{2} ; 1.8 \mathrm{CaCl}_{2} ; 5$ HEPES; $30 \mathrm{KCl} ; 10$ glucose; pH 7.4 with $\mathrm{NaOH}$. ZD7288 was obtained from Tocris (Ellisville, MO, USA).
Calcium imaging Experiments were carried out using an Olympus BX51W1 fluorescent microscope (Olympus Canada, Markham, ON, Canada). Changes in intracellular $\mathrm{Ca}^{2+}$ concentrations $\left[\mathrm{Ca}^{2+}\right]_{\mathrm{i}}$ were assessed using Fura-2 AM. Alpha-TC6 cells on coverslips were loaded with $2.5 \mu \mathrm{mol} / 1$ Fura-2 AM for $45 \mathrm{~min}$ in incubation buffer at $37^{\circ} \mathrm{C}$ and $5 \% \mathrm{CO}_{2}-95 \%$ air. Then coverslips were transferred to an open chamber on the microscope stage for imaging and perfused at $1 \mathrm{ml} / \mathrm{min}$. The incubation and perfusion buffer contained (mmol/l): $130 \mathrm{NaCl}, 5 \mathrm{KCl}$, $2 \mathrm{CaCl}_{2}, 1 \mathrm{MgCl}_{2}, 5 \mathrm{NaHCO}_{3}, 10$ HEPES, pH 7.4. To depolarise the cells, $30 \mathrm{mmol} / 1 \mathrm{NaCl}$ was replaced with $30 \mathrm{mmol} / 1 \mathrm{KCl}$. Cells were excited by dual excitation at $340 / 380 \mathrm{~nm}$ and emission was detected by a $510 \mathrm{~nm}$ band pass filter using a $415 \mathrm{~nm}$ beam splitter. Experiments were performed at $36-37^{\circ} \mathrm{C}$ using a TC-324B Heater Controller (Warner Instruments, Hamden, CT, USA).

Glucagon secretion Glucagon secretion in the clonal alpha cells was measured using a glucagon RIA kit (Linco Research, St Charles, MO, USA) as described previously [27]. For islet assay, Krebs-Ringer bicarbonate buffer (KRB) was used containing (mmol/l) $115 \mathrm{NaCl}, 5 \mathrm{KCl}$, $24 \mathrm{NaHCO}_{3}, 2.5 \mathrm{CaCl}_{2}, 1 \mathrm{MgCl}_{2}, 10$ HEPES and $\%$ (wt/vol.) BSA. Islets were pre-incubated at $37^{\circ} \mathrm{C}$ for $30 \mathrm{~min}$ in $\mathrm{KRB}$ supplemented with $5.6 \mathrm{mmol} / \mathrm{l}$ glucose and then transferred to $1.5 \mathrm{ml}$ tubes for assay (five islets per sample). The islets were first incubated in $500 \mu \mathrm{KRB}$ with $11 \mathrm{mmol} / \mathrm{l}$ glucose for $1 \mathrm{~h}$ at $37^{\circ} \mathrm{C}$, and then in $500 \mu \mathrm{KRB}$ with $1 \mathrm{mmol} / 1$ glucose for an additional $1 \mathrm{~h}$ at $37^{\circ} \mathrm{C}$. The supernatant fractions $(450 \mu \mathrm{l})$ from each sample were taken at the end of the incubation period and stored at $-20^{\circ} \mathrm{C}$ until assayed for glucagon. The islet pellets were lysed with acid ethanol $(0.09 \mathrm{~mol} / \mathrm{l} \mathrm{HCl}$ in $75 \%$ [vol./vol.] ethanol) for DNA quantification; glucagon secretion data were normalised by total DNA of each sample.

Statistical analysis All data are presented as means \pm SEM. Statistical analysis was done by a Student's $t$ test or paired $t$ test or ANOVA using $n-1$ custom hypotheses tests as appropriate. Patch-clamp data were analysed with IGOR Pro3.12 software (Wavemetrics, Lake Oswego, OR, USA) and the data of fluorescent measurements were processed using PSI-PLOT (Poly Software International, Salt Lake City, UT, USA). Significance was assumed at $p<0.05$.

\section{Results}

HCN channels are expressed in glucagon-secreting alpha cells RT-PCR showed the presence of the transcripts coding for HCN proteins in glucagon-secreting alpha-TC6 cells and rat islets (Fig. 1a). Immunostaining predominantly 
a
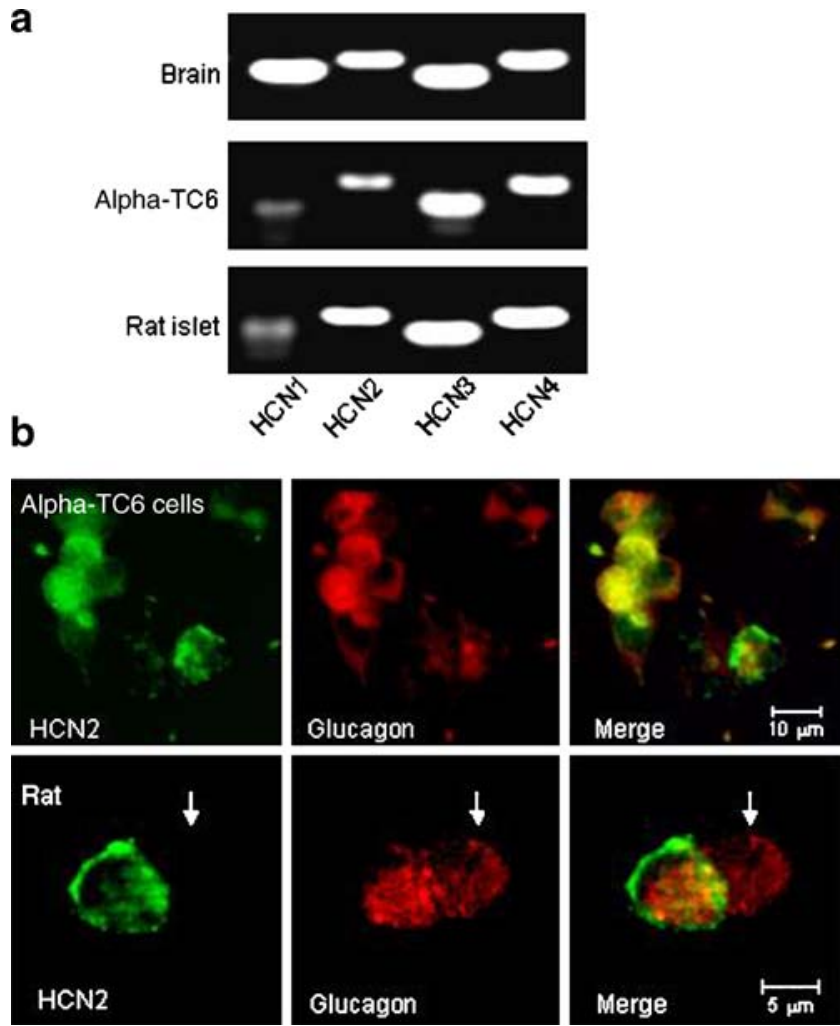

Fig. 1 Presence of HCN transcripts and proteins in alpha cells. a Total RNA from alpha-TC6 cells and rat islets was reverse transcribed into cDNA and PCR analysis was performed with specific primers for the HCN1-4 subtypes. In the negative control reaction, the template was omitted (not shown). b Confocal immunocytochemistry of alphaTC6 cells and dispersed rat islet cells using the antibody against the HCN2 subtype. Scale bar, $10 \mu \mathrm{m}$. The white arrows indicate the rat islet cell that is glucagon-positive but not HCN2. In the negative control staining, either the primary antibodies were omitted or COS-7 cells were used (not shown). The data shown represent $n=3$ or 4 independent experiments

detected HCN2 proteins in alpha-TC6 cells and dispersed rat alpha cells (Fig. 1b). In the control experiments, no positive staining was observed when omitting the primary antibodies during the staining procedures (not shown). Interestingly, we also found that while most glucagonpositive alpha cells are HCN-positive, a few glucagonpositive cells were not associated with $\mathrm{HCN}$ protein (Fig. 1b [white arrows indicate the glucagon-positive but HCN2-negative rat islet cell]), which is also suggestive of a specific immunostaining.

Electrophysiological properties of HCN channels in alphaTC6 cells Cells were clamped from a holding potential of $-40 \mathrm{mV}$ to various hyperpolarising conditioning voltages ( -140 to $-50 \mathrm{mV}$ in $10 \mathrm{mV}$ increments) for $3 \mathrm{~s}$ followed by a step to $-140 \mathrm{mV}$ (Fig. 2a). The recordings showed that the hyperpolarising voltages induced inward currents with slow activation kinetics (Fig. 2b). To construct the steadystate activation curve of these channels, the tail currents measured at $-140 \mathrm{mV}$ immediately after the conditioning voltages (indicated by an arrow in Fig. 2b) were normalised and plotted as a function of the conditioning membrane voltages, then the data were fitted using the Boltzmann equation [28]. As shown (Fig. 2c), under the conditioning voltages, the amplitudes of the peak tail current displayed a typical sigmoidal property [25] and the membrane potential of half-maximal activation $\left(V_{1 / 2}\right)$ was found to be $-102 \pm 1 \mathrm{mV}$ (the slope factor: $7.8 \pm 0.1 \mathrm{mV}, n=6$ ).

To examine the reversal potential, another protocol was used. A pre-hyperpolarising pulse to $-140 \mathrm{mV}$ was applied in order to maximally activate HCN channels, and the membrane was then clamped back to test pulses ranging from -70 to $-20 \mathrm{mV}$ (Fig. 2d). The tail currents were measured under the test pulses (Fig. 2e) and a currentvoltage $(I / V)$ relationship of the fully activated HCN channels was made by plotting the tail currents against the test potentials, and the reversal potential was found to be $-33 \mathrm{mV}$ (Fig. 2f). ZD7288, an HCN channel blocker [29] was used to verify the specificity of the HCN channel current in alpha-TC6 cells. As shown, the sustained HCN channel currents obtained from the cells clamped at $-140 \mathrm{mV}$ were significantly blocked by $50 \mu \mathrm{mol} / \mathrm{LD} 7288$ (Fig. 2g, h; the blockade $=65.3 \pm 6.8 \%, p<0.01, n=6$ ). Therefore, these channels possess typical characteristics of $\mathrm{HCN}$ channels as reported $[25,30]$.

HCN channels modulate glucagon secretion in alpha cell lines To determine the functional role of HCN channels in alpha cells, we measured glucagon release by RIA. Our data showed that high glucose $(20 \mathrm{mmol} / \mathrm{l})$ significantly suppressed glucagon release compared with low glucose ( $2 \mathrm{mmol} / \mathrm{l}$ ) in alpha-TC6 cells (Fig. 3a, $p<0.05, n=4)$. Treatment with ZD7288 (100 $\mu \mathrm{mol} / 1,30 \mathrm{~min})$ enhanced glucagon secretion by $\sim 65 \%(p<0.05, n=4)$ and $\sim 78 \%(p<0.05$, $n=4)$ in the presence of either low $(2 \mathrm{mmol} / \mathrm{l})$ or high (20 mmol/l) glucose, respectively (Fig. 3a). Similar results were observed with IN-R1-G9 cells (Fig. 3b), another wellestablished alpha cell line. Conversely, the HCN channel agonist lamotrigine significantly suppressed glucagon secretion from alpha-TC6 cells at $2 \mathrm{mmol} / 1$ glucose (Fig. 3c; $n=4, p<0.05$ ), but had no effect on glucagon secretion in the presence of $20 \mathrm{mmol} / \mathrm{l}$ glucose. Similar results were also seen with IN-R1-G9 cells (Fig. 3d). These data indicate that modulation of HCN channel activity alters secretory function in alpha cells.

$\mathrm{Ca}^{2+}$ and $\mathrm{Na}^{+}$channels mediate HCN channel function in alpha-TC6 cells To further establish the mechanism by which alteration of $\mathrm{HCN}$ channel activity modulates glucagon secretion, we measured $\left[\mathrm{Ca}^{2+}\right]_{\mathrm{i}}$ in response to HCN channel blocker ZD7288 in alpha-TC6 cells. As shown, blockade of the HCN channels by ZD7288 


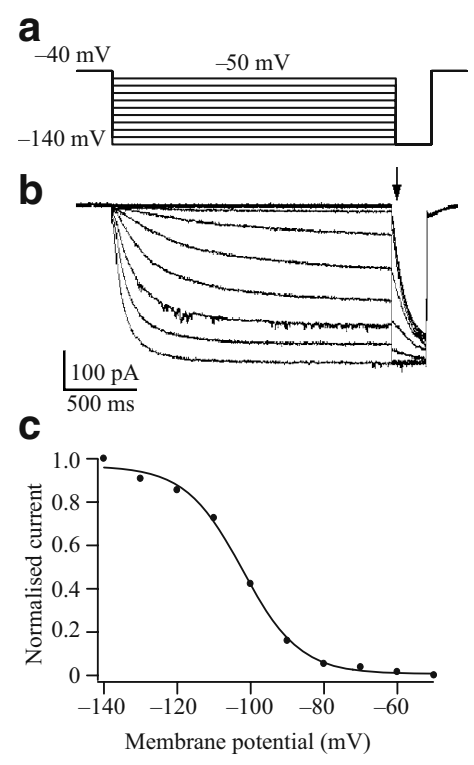

Fig. 2 Characterisation of functional HCN channels in alpha-TC6 cells. Cells were clamped from a holding potential of $-40 \mathrm{mV}$ to various hyperpolarising conditioning voltages $(-140$ to $-50 \mathrm{mV}$ ) followed by a step to $-140 \mathrm{mV}$ (a). Representative current traces were induced under this voltage protocol (b). c The tail currents measured at $-140 \mathrm{mV}$ immediately after the conditioning voltages (indicated by an arrow in b) were normalised and plotted as a function of the conditioning voltages. The $V_{1 / 2}$ is $-102 \pm 1 \mathrm{mV}(n=6)$. d To determine the $I / V$ relationship of the fully activated $\mathrm{HCN}$ channels, the protocol g
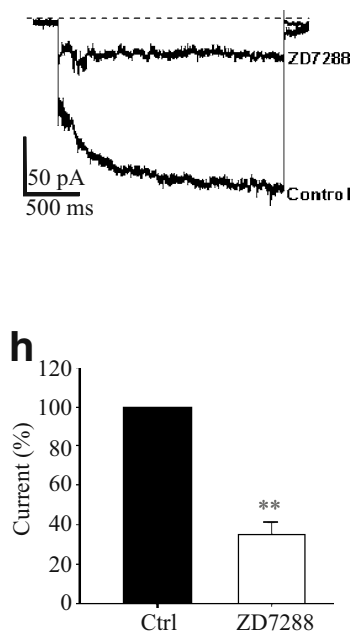

a
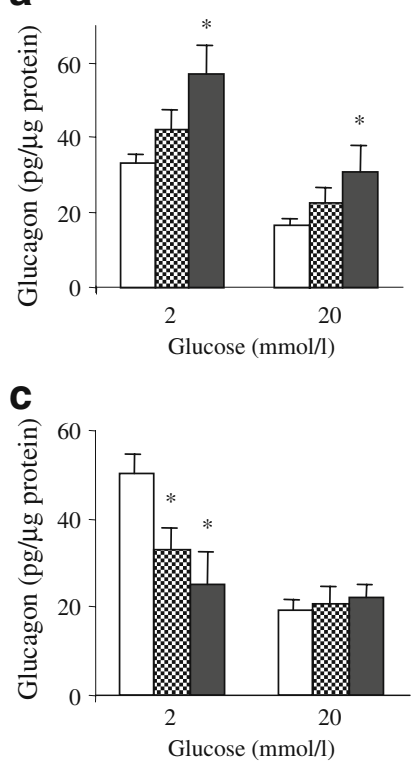

b
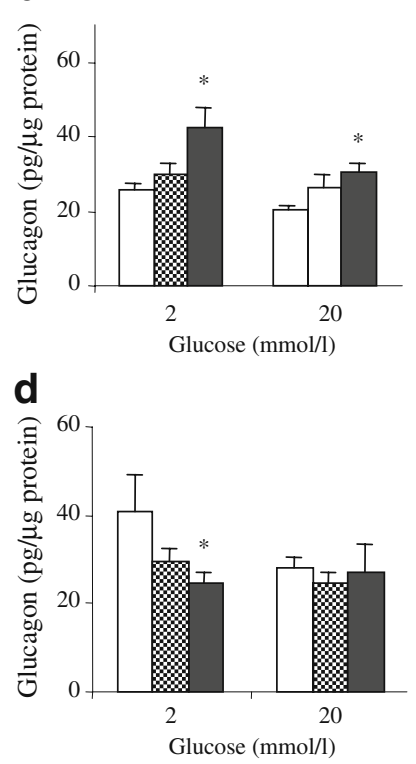

Fig. $3 \mathrm{HCN}$ channels modulate glucagon secretion in alpha cells. Glucagon secretion from alpha-TC6 cells $(\mathbf{a}, \mathbf{c})$ or IN-R1-G9 cells (b, d) measured by RIA in the presence of different concentrations of ZD7288 (a, b) or lamotrigine (c, d) at low $(2 \mathrm{mmol} / \mathrm{l})$ or high (20 mmol/l) glucose (white columns, $0 \mu \mathrm{mol} / \mathrm{l}$; chequered columns, $10 \mu \mathrm{mol} / \mathrm{l}$; black columns, $100 \mu \mathrm{mol} / \mathrm{l}) .{ }^{*} p<0.05, n=4$ for each group

significantly increased $\left[\mathrm{Ca}^{2+}\right]_{\mathrm{i}}$ (Fig. 4a), while lamotrigine $(10 \mu \mathrm{mol} / \mathrm{l})$ attenuated the action of ZD7288 on $\left[\mathrm{Ca}^{2+}\right]_{\mathrm{i}}$ (Fig. 4a). As a positive control, application of depolarising amounts of $\mathrm{KCl}(30 \mathrm{mmol} / \mathrm{l})$ further enhanced $\left[\mathrm{Ca}^{2+}\right]_{\mathrm{i}}$. These findings indicate that the effect of $\mathrm{HCN}$ channels on glucagon secretion in alpha cells is mediated by modulating $\left[\mathrm{Ca}^{2+}\right]_{\mathrm{i}}$.

Alpha cells are equipped with $\mathrm{Na}^{+}$channels that are critical in the generation of action potential and modulation of glucagon secretion [11, 14, 31]. Therefore, we sought to determine if the $\mathrm{Na}^{+}$channel is involved in the process of $\mathrm{HCN}$ channel-mediated modulation of glucagon secretion in alpha-TC6 cells. To this end, we determined if blocking the $\mathrm{Na}^{+}$channel alters the effect of $\mathrm{HCN}$ channels on $\left[\mathrm{Ca}^{2+}\right]_{\mathrm{i}}$. As shown, blockade of the $\mathrm{Na}^{+}$channels by using the specific blocker TTX $(0.3 \mu \mathrm{mol} / \mathrm{l})$ significantly attenuated the elevation of $\left[\mathrm{Ca}^{2+}\right]_{\mathrm{i}}$ induced by ZD7288 (Fig. 4b,c; ZD7288 vs ZD7288+TTX $100 \%$ vs $36 \%, p<0.001, n=3$ ), suggesting that the $\mathrm{HCN}$ channel-induced $\left[\mathrm{Ca}^{2+}\right]_{\mathrm{i}}$ change is mediated by $\mathrm{Na}^{+}$channels in alpha cells.

HCN channels modulate glucagon secretion from rat islets The findings from the clonal alpha cells indicate that modulation of $\mathrm{HCN}$ channel activity alters intracellular $\mathrm{Ca}^{2+}$ 
a

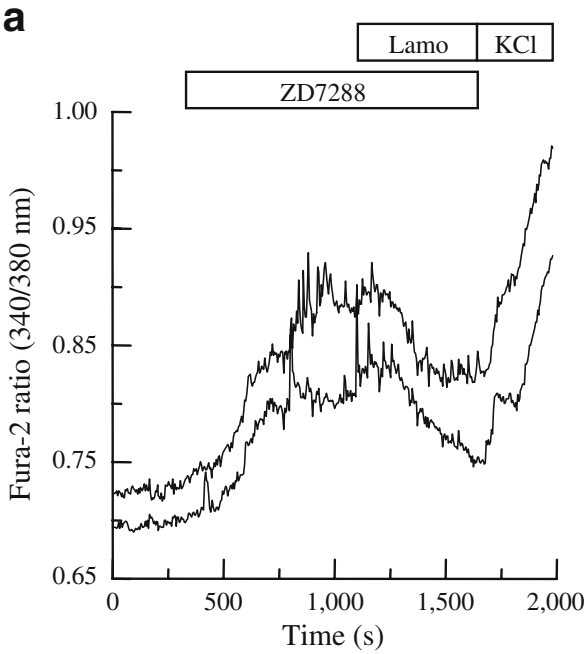

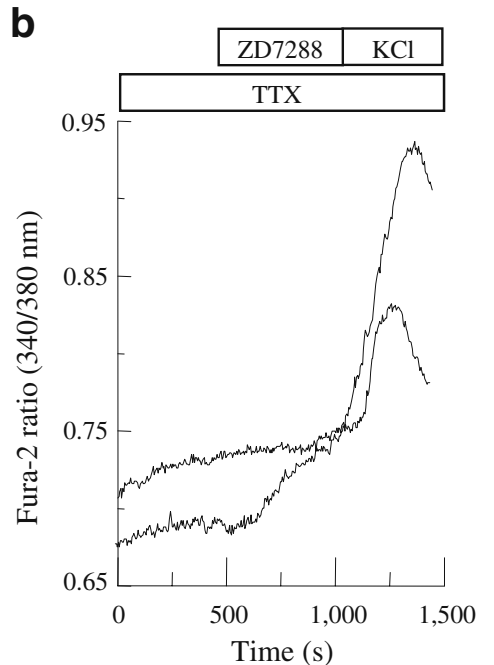

C

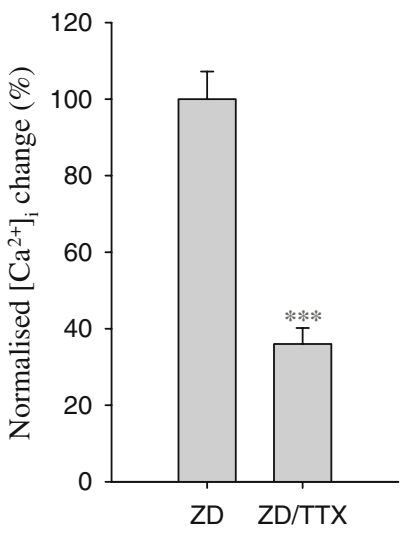

Fig. $4 \mathrm{Ca}^{2+}$ and $\mathrm{Na}^{+}$channels mediate $\mathrm{HCN}$ channel function in alpha-TC6 cells. Cells loaded with Fura-2 AM were perfused with buffer containing $1 \mathrm{mmol} / 1$ glucose in the absence (a) or presence of $0.3 \mu \mathrm{mol} / 1 \mathrm{TTX}(\mathbf{b})$ as indicated and were then challenged with $60 \mu \mathrm{mol} / 1 \mathrm{ZD} 7288$ or plus $10 \mu \mathrm{mol} / 1$ lamotrigine (Lamo) followed by perfusion of $30 \mathrm{mmol} / 1 \mathrm{KCl}$. Three independent experiments were performed in each case, and 7-15 cells were measured from each experiment. Only those cells that exhibited depolarised responses to $\mathrm{KCl}$ were chosen for analysis. For clarity, the representative $\left[\mathrm{Ca}^{2+}\right]_{\mathrm{i}}$ traces of two individual cells are shown in each case. c The normalised $\left[\mathrm{Ca}^{2+}\right]_{\mathrm{i}}$ changes induced by ZD7288 (ZD) (a) and ZD7288 plus TTX (b) are shown $(n=3, * * * p<0.001)$

creased at both 1 and $11 \mathrm{mmol} / \mathrm{l}$ glucose conditions when treated with $5 \mu \mathrm{mol} / \mathrm{l}$ cilobradine (Fig. $5, p<0.05$ vs control). these phenomena are of physiological relevance, we performed glucagon secretion RIA using isolated rat islets. Our data showed that treatment of ZD7288 (100 $\mu \mathrm{mol} / \mathrm{l}$, $60 \mathrm{~min})$ significantly enhanced glucagon secretion at $1 \mathrm{mmol} / \mathrm{l}$ glucose conditions compared with the control (Fig. 5, $1.44 \pm 0.16$ vs $0.86 \pm 0.19 \mathrm{pg} / \mu \mathrm{g}$ DNA, $p<0.05$ ), whereas ZD7288 had no significant effect on glucagon secretion under $11 \mathrm{mmol} / 1$ glucose (Fig. 5, $0.64 \pm 0.06$ vs $0.56 \pm 0.20 \mathrm{pg} / \mu \mathrm{g}$ DNA, $p>0.05)$. We repeated the same experiment with another $\mathrm{HCN}$ channel blocker, cilobradine, and found that glucagon secretion was substantially in-

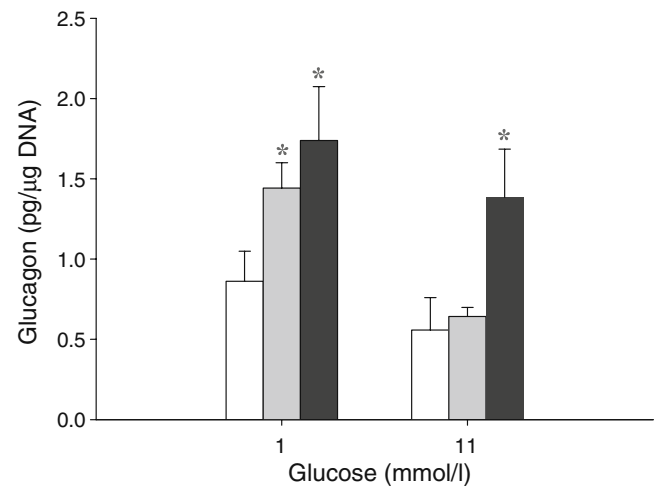

Fig. $5 \mathrm{HCN}$ channels modulate glucagon secretion from rat islets. Glucagon secretion from alpha cells in rat islets was measured at 1 or $11 \mathrm{mmol} / 1$ glucose, in the absence (white bars) or presence of ZD7288 ( $100 \mu \mathrm{mol} / 1$, grey bars) or cilobradine $\left(5 \mu \mathrm{mol} / 1\right.$, black bars). ${ }^{*} p<0.05$ vs control, $n=6$

\section{Discussion}

We first detected the presence of $\mathrm{HCN}$ channels in the alpha-TC6 cell line and rat islet alpha cells. Furthermore, using the patch-clamp technique, the hyperpolarisationactivated inward currents were consistently detected in alpha-TC6 cells. The steady-state voltage activation curve revealed that $V_{1 / 2}$ was $-102 \pm 1 \mathrm{mV}$, which is comparable to those of HCN channels detected in cardiac cells [25] and neuronal cells [30]. The reversal potential of $-33 \mathrm{mV}$ obtained from the fully activated inward currents in alphaTC6 cells suggests that this channel is permeable to both $\mathrm{Na}^{+}$and $\mathrm{K}^{+}$[32], which represents the typical characteristics of $\mathrm{HCN}$ channels as reported in other cell types [25, 30, 33]. Additionally, ZD7288, an HCN channel blocker, significantly blocked these currents, indicating that the slow-activating inward currents in alpha cells were indeed from $\mathrm{HCN}$ channels.

The physiological functions of $\mathrm{HCN}$ channels in alpha cells were then examined in this study. We found that blockade of HCN channels by ZD7288 significantly enhanced glucagon release from both alpha-TC6 cells and IN-R1-G9 cells. We have shown in a previous study that ZD7288 directly exerts an inhibitory effect on exocytosis, in addition to inhibiting HCN channels [26]. We also found that ZD7288 has no effects on 

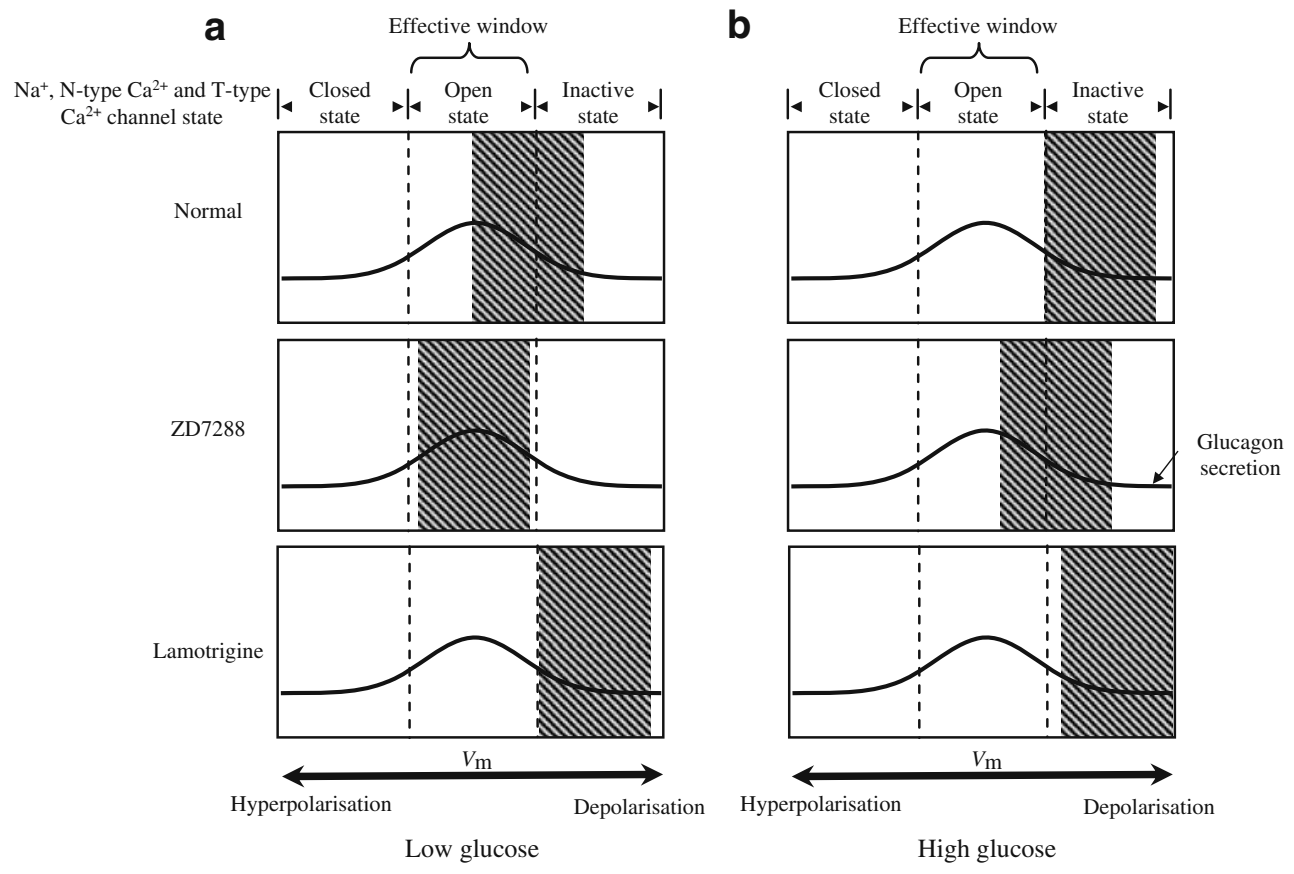

Fig. 6 A model showing $\mathrm{HCN}$ channel-mediated regulation of glucagon secretion in alpha cells under normal conditions, or with ZD7288 or lamotrigine treatments. Schematic representation of the effects of HCN channels on alpha cell membrane potential and $\mathrm{Na}^{+}$ and $\mathrm{N}$ - and T-type $\mathrm{Ca}^{2+}$ channel activities and glucagon secretion. Alpha cell membrane potential $\left(V_{\mathrm{m}}\right)$ change is indicated by the lower arrow bar. $\mathrm{Na}^{+}, \mathrm{N}$-type $\mathrm{Ca}^{2+}$ and T-type $\mathrm{Ca}^{2+}$ channel activities are shown by their gating states (closed, open and inactive state) at different membrane potential levels. The open state area represents the

voltage-dependent potassium channels, calcium channels and $\mathrm{K}_{\mathrm{ATP}}$ channels (M. B. Wheeler, unpublished data). Therefore, the stimulatory effect of $\mathrm{HCN}$ channel inhibition by ZD7288 on the glucagon secretion might be underestimated because of its direct inhibitory effect on exocytosis. Lamotrigine has been reported as a $\mathrm{Na}^{+}$channel inhibitor [34], but this drug activates $\mathrm{HCN}$ channels in pyramidal neurons without affecting $\mathrm{Na}^{+}$channels $[35,36]$. We found that lamotrigine did not significantly influence $\mathrm{Na}^{+}$channels in alpha cells at low concentration $(10 \mu \mathrm{mol} / \mathrm{l}$, data not shown), while $10 \mu \mathrm{mol} / 1$ lamotrigine led to suppression of glucagon secretion. These results indicate that alterations in $\mathrm{HCN}$ channel activity affect glucagon secretion in alpha cells. To establish the underlying mechanism, we examined the intracellular $\mathrm{Ca}^{2+}$ responses in alpha-TC6 cells. As expected, inhibition of the HCN channels by ZD7288 caused a significant increase of $\left[\mathrm{Ca}^{2+}\right]_{i}$, while activation of $\mathrm{HCN}$ channels by $10 \mu \mathrm{mol} / \mathrm{l}$ lamotrigine attenuated the effects of ZD7288.

Activation of alpha cell voltage-gated $\mathrm{Ca}^{2+}$ channels and the resultant glucagon secretion requires the activation of $\mathrm{Na}^{+}$channels. Several reports have shown that pharmacological blockade of $\mathrm{Na}^{+}$channels inhibits glucagon secretion $[11,14,18,31]$. Given that we had observed an alpha cell membrane potential 'window', where glucagon release is triggered through the activation of $\mathrm{Na}^{+}$and $\mathrm{Ca}^{2+}$ channels. When the alpha cell is too depolarised or too hyperpolarised, the channels then switch to inactive states or closed states, respectively. Under both conditions, no action potential can be generated and glucagon secretion is suppressed. The hatched grey areas represent the 'actual membrane potential' upon involvement of the HCN channels at low (a) and high (b) glucose concentrations. (see "Discussion" section for details)

augmentation of $\left[\mathrm{Ca}^{2+}\right]_{\mathrm{i}}$ associated with enhanced glucagon secretion upon inhibition of HCN channels, we hypothesised that $\mathrm{Na}^{+}$channels might mediate these effects. To verify this, we have tested the effect of $\mathrm{Na}^{+}$channel blocker TTX on ZD7288-induced $\left[\mathrm{Ca}^{2+}\right]_{\mathrm{i}}$ change. Indeed, we found that TTX could significantly attenuate ZD7288-induced $\left[\mathrm{Ca}^{2+}\right]_{\mathrm{i}}$ elevation, indicating that the $\mathrm{Na}^{+}$channel is downstream of the HCN channel function in alpha cells.

In a more physiological setting, we determined if changes in $\mathrm{HCN}$ channel activity alter glucagon secretion in rat alpha cells. Consistently, we found that blockage of $\mathrm{HCN}$ by ZD7288 at $1 \mathrm{mmol} / \mathrm{l}$ glucose conditions significantly increased glucagon secretion from the rat islets, while no significant effect was observed under $11 \mathrm{mmol} / \mathrm{l}$ glucose. The lesser effect of ZD7288 on glucagon secretion at high glucose is probably because of the hyperpolarisation-activated characteristics of $\mathrm{HCN}$ channels; they are supposed to be less active when the membranes are depolarised under high glucose concentrations. Interestingly, compared with the effect of ZD7288, we found that cilobradine led to a stronger enhancement of glucagon secretion at both 1 and $11 \mathrm{mmol} / \mathrm{l}$ glucose conditions. Given that cilobradine is also a voltagedependent potassium $\left(\mathrm{K}_{\mathrm{V}}\right)$ channel inhibitor [26] and that, 
blockade of $\mathrm{K}_{\mathrm{V}}$ channel causes enhancement of cellular secretion [12], it is possible that the profound effect of cilobradine on glucagon secretion is probably via both $\mathrm{HCN}$ channel and $\mathrm{K}_{\mathrm{V}}$ channel pathways. However, because of the complicated paracrine interactions among islet alpha, beta and delta cells, it is difficult to make a precise interpretation of the results obtained from islet cells. Nevertheless, the consistent findings that inactivating HCN channels increases glucagon secretion from clonal glucagon-secreting cells and isolated rat islets suggest an important role for $\mathrm{HCN}$ channels in modulating glucagon secretion from alpha cells.

It is interesting that in pancreatic beta cells, HCN channels do not seem to play a crucial role in modulating insulin secretion [26]. The difference might be attributed to the unique biophysical properties of alpha cells. Numerous studies have demonstrated that: (1) alpha cell $\mathrm{K}_{\mathrm{ATP}}$ channels are more sensitive to ATP inhibition than those in beta cells; thus, the $\mathrm{K}_{\mathrm{ATP}}$ channels in alpha cells possess intermediate activity under low glucose concentrations [3, 11, 31, 37]; (2) unlike the beta cell $\mathrm{Na}^{+}$channels, which are activated at a more negative membrane potential, the alpha cell $\mathrm{Na}^{+}$ channels are active within a physiological range of membrane potentials $[14,17,31]$; and (3) in addition to the L-type $\mathrm{Ca}^{2+}$ channels that are the most important in modulating $\left[\mathrm{Ca}^{2+}\right]_{\mathrm{i}}$ in beta cells, the activities of T-type and N-type $\mathrm{Ca}^{2+}$ channels in alpha cells are critical in the generation of action potentials and control of glucagon secretion [11, 14, 15, 38]. Based on these findings, it has been proposed that glucagon secretion only occurs within a narrow window of intermediate alpha cell $\mathrm{K}_{\mathrm{ATP}}$ channel activity (e.g. under low glucose conditions), where the membrane potential elicits regenerative electrical activities through the activation of $\mathrm{Na}^{+}$and $\mathrm{T}$ - and N-type $\mathrm{Ca}^{2+}$ channels $[10,11,14]$.

The present study suggests a potential role for HCN channels in regulation of glucagon secretion via modulating the regenerative electrical activities in alpha cells (Fig. 6). It is likely that under low glucose conditions the inward $\mathrm{HCN}$ currents cause a slight alpha cell depolarisation that leads to inactivation of a small fraction of the $\mathrm{Na}^{+}$and $\mathrm{T}-$ and N-type $\mathrm{Ca}^{2+}$ channels, partly suppressing glucagon secretion (grey hatched in Fig. 6a, upper panel). While with treatment of ZD7288, the blockade of inward HCN currents causes a slight membrane hyperpolarisation, this would release more $\mathrm{Na}^{+}$and $\mathrm{Ca}^{2+}$ channels from their inactive state, making them available to be activated, and as a consequence, increasing alpha cell electrical activity and glucagon secretion (grey hatched in Fig. 6a, middle panel). Conversely, the enhancement of inward $\mathrm{HCN}$ currents induced by lamotrigine further depolarises the membrane to a level that is out of the effective window, resulting in the inactivation of $\mathrm{Na}^{+}$and $\mathrm{T}-$ and $\mathrm{N}$-type $\mathrm{Ca}^{2+}$ channels and the suppression of glucagon secretion (grey hatched in
Fig. 6a, lower panel). Given the hyperpolarisation-activated characteristics of $\mathrm{HCN}$ channels, they would be anticipated to be less active under high glucose concentrations (i.e. membrane depolarisation conditions) (grey hatched in Fig. 6b). Nevertheless, under high glucose concentrations, inactivation of $\mathrm{HCN}$ channels still resulted in an induction of glucagon secretion.

The physiological relevance of HCN channels in alpha cells is at present not clear. It is known that paracrine factors including insulin, zinc and GABA play important roles in modulating glucose-regulated glucagon secretion [39]. A recent study suggested that glutamate released from alpha cells exerts autocrine effects to produce adequate glucagon release under hypoglycaemic conditions [40]. Given that, physiologically, a negative feedback simultaneously occurs during a secretory process, it is possible that the HCN channel in alpha cells may function as a negative feedback modulator to prevent an 'overshooting' of glucagon secretion under glucagon-stimulatory conditions, hence to maintain the hormone at appropriate levels.

It now remains to be seen how HCN channel activation is affected under physiological conditions. Our experiments have shown that the increase of intracellular cAMP only caused a $3 \mathrm{mV}$ right shift of the voltage activation curve for HCN channels in alpha-TC6 cells (data not shown), and it appears that cAMP has less effect in modulating the activity of HCN channels in alpha-TC6 cells. Considering the recent report that phosphatidylinositol 4,5-bisphosphate activates HCN channels in Xenopus oocytes via a cAMPindependent pathway [41], and that elevation of cAMP initiates multiple pathways with divergent components, further investigations to determine the precise molecular mechanism that underlies $\mathrm{HCN}$ channel regulation in alpha cells are required and will provide new information and potential therapeutic targets to optimise the treatment of diabetes.

Acknowledgements This work was supported by operating grants from the Canadian Institute for Health research (CIHR) (MOP-49521 to M. B. Wheeler and MOP-79534 to Q. Wang). H. Y. Gaisano is supported by the Juvenile Diabetes Research Foundation (1-20051112). Q. Wang was a Canadian Diabetes Association Scholar and is a recipient of a New Investigator Award from CIHR. The authors thank J. MacDonald (University of Toronto, Canada) for providing tetrodotoxin as a gift, M. Braun (Lund University, Sweden) for useful discussion and critical reading of the manuscript, and A. Hyder for performing some glucagon RIAs.

Duality of interest The authors declare that there is no duality of interest associated with this manuscript.

\section{References}

1. Ashcroft FM, Rorsman P (1989) Electrophysiology of the pancreatic beta-cell. Prog Biophys Mol Biol 54:87-143 
2. Greenbaum CJ, Havel PJ, Taborsky GJ Jr, Klaff LJ (1991) Intraislet insulin permits glucose to directly suppress pancreatic A cell function. J Clin Invest 88:767-773

3. Leung YM, Ahmed I, Sheu L et al (2006) Insulin regulates islet alpha-cell function by reducing KATP channel sensitivity to adenosine 5'-triphosphate inhibition. Endocrinology 147:2155-2162

4. Ravier MA, Rutter GA (2005) Glucose or insulin, but not zinc ions, inhibit glucagon secretion from mouse pancreatic alphacells. Diabetes 54:1789-1797

5. Ishihara H, Maechler P, Gjinovci A, Herrera PL, Wollheim CB (2003) Islet beta-cell secretion determines glucagon release from neighbouring alpha-cells. Nat Cell Biol 5:330-335

6. Franklin IK, Wollheim CB (2004) GABA in the endocrine pancreas: its putative role as an islet cell paracrine-signalling molecule. J Gen Physiol 123:185-190

7. Wendt A, Birnir B, Buschard K et al (2004) Glucose inhibition of glucagon secretion from rat alpha-cells is mediated by GABA released from neighboring beta-cells. Diabetes 53:1038-1045

8. Xu E, Kumar M, Zhang Y et al (2006) Intra-islet insulin suppresses glucagon release via GABA-GABAA receptor system. Cell Metab 3:47-58

9. Cejvan K, Coy DH, Efendic S (2003) Intra-islet somatostatin regulates glucagon release via type 2 somatostatin receptors in rats. Diabetes 52:1176-1181

10. Gromada J, Franklin I, Wollheim CB (2007) Alpha-cells of the endocrine pancreas: 35 years of research but the enigma remains. Endocr Rev 28:84-116

11. MacDonald PE, De Marinis YZ, Ramracheya R et al (2007) A K ATP channel-dependent pathway within alpha cells regulates glucagon release from both rodent and human islets of Langerhans. PLoS Biol 5:e143

12. MacDonald PE, Wheeler MB (2003) Voltage-dependent $\mathrm{K}(+)$ channels in pancreatic beta cells: role, regulation and potential as therapeutic targets. Diabetologia 46:1046-1062

13. Gopel S, Zhang Q, Eliasson L et al (2004) Capacitance measurements of exocytosis in mouse pancreatic alpha-, beta- and deltacells within intact islets of Langerhans. J Physiol 556:711-726

14. Gopel SO, Kanno T, Barg S, Weng XG, Gromada J, Rorsman P (2000) Regulation of glucagon release in mouse $\alpha$-cells by KATP channels and inactivation of TTX-sensitive $\mathrm{Na}^{+}$channels. J Physiol 528:509-520

15. Leung YM, Ahmed I, Sheu L, Tsushima RG, Diamant NE, Gaisano HY (2006) Two populations of pancreatic islet alpha-cells displaying distinct $\mathrm{Ca}^{2+}$ channel properties. Biochem Biophys Res Commun 345:340-344

16. Olsen HL, Theander S, Bokvist K, Buschard K, Wollheim CB, Gromada J (2005) Glucose stimulates glucagon release in single rat alpha-cells by mechanisms that mirror the stimulus-secretion coupling in beta-cells. Endocrinology 146:4861-4870

17. Rorsman P, Hellman B (1988) Voltage-activated currents in guinea pig pancreatic alpha 2 cells. Evidence for $\mathrm{Ca}^{2+}$-dependent action potentials. J Gen Physiol 91:223-242

18. Gromada J, Ma X, Hoy M et al (2004) ATP-sensitive $\mathrm{K}^{+}$channeldependent regulation of glucagon release and electrical activity by glucose in wild-type and SUR1-/- mouse alpha-cells. Diabetes 53 (Suppl 3):S181-S189

19. DiFrancesco D (1993) Pacemaker mechanisms in cardiac tissue. Annu Rev Physiol 55:455-472

20. Luthi A, McCormick DA (1998) H-current: properties of a neuronal and network pacemaker. Neuron 21:9-12

21. Maccaferri G, McBain CJ (1996) The hyperpolarization-activated current (Ih) and its contribution to pacemaker activity in rat CA1 hippocampal stratum oriens-alveus interneurones. J Physiol 497:119-130
22. Robinson RB, Siegelbaum SA (2003) Hyperpolarization-activated cation currents: from molecules to physiological function. Annu Rev Physiol 65:453-480

23. Santoro B, Liu DT, Yao H et al (1998) Identification of a gene encoding a hyperpolarization-activated pacemaker channel of brain. Cell 93:717-729

24. Santoro B, Tibbs GR (1999) The HCN gene family: molecular basis of the hyperpolarization-activated pacemaker channels. Ann N Y Acad Sci 868:741-764

25. Ludwig A, Zong X, Stieber J, Hullin R, Hofmann F, Biel M (1999) Two pacemaker channels from human heart with profoundly different activation kinetics. EMBO J 18:23232329

26. El Kholy W, MacDonald PE, Fox JM et al (2007) Hyperpolarizationactivated cyclic nucleotide-gated channels in pancreatic beta-cells. Mol Endocrinol 21:753-764

27. Zhao Y, Liu T, Zhang N et al (2005) Role of Cdx-2 in insulin and proglucagon gene expression: a study using the RIN-1056A cell line with an inducible gene expression system. J Endocrinol 186:179-192

28. Yagi J, Sumino R (1998) Inhibition of a hyperpolarizationactivated current by clonidine in rat dorsal root ganglion neurons. J Neurophysiol 80:1094-1104

29. Beaumont V, Zucker RS (2000) Enhancement of synaptic transmission by cyclic AMP modulation of presynaptic Ih channels. Nat Neurosci 3:133-141

30. Yu X, Duan KL, Shang CF, Yu HG, Zhou Z (2004) Calcium influx through hyperpolarization-activated cation channels (I(h) channels) contributes to activity-evoked neuronal secretion. Proc Natl Acad Sci U S A 101:1051-1056

31. Barg S, Galvanovskis J, Gopel SO, Rorsman P, Eliasson L (2000) Tight coupling between electrical activity and exocytosis in mouse glucagon-secreting alpha-cells. Diabetes 49:1500-1510

32. Tian L, Shipston MJ (2000) Characterization of hyperpolarizationactivated cation currents in mouse anterior pituitary, AtT20 D16:16 corticotropes. Endocrinology 141:2930-2937

33. Kaupp UB, Seifert R (2001) Molecular diversity of pacemaker ion channels. Annu Rev Physiol 63:235-257

34. Zona C, Avoli M (1997) Lamotrigine reduces voltage-gated sodium currents in rat central neurons in culture. Epilepsia 38:522-525

35. Poolos NP, Migliore M, Johnston D (2002) Pharmacological upregulation of h-channels reduces the excitability of pyramidal neuron dendrites. Nat Neurosci 5:767-774

36. Zhong N, Zucker RS (2005) cAMP acts on exchange protein activated by cAMP/cAMP-regulated guanine nucleotide exchange protein to regulate transmitter release at the crayfish neuromuscular junction. J Neurosci 25:208-214

37. Leung YM, Ahmed I, Sheu L et al (2005) Electrophysiological characterization of pancreatic islet cells in the mouse insulin promoter-green fluorescent protein mouse. Endocrinology 146:4766-4775

38. Rorsman P (1988) Two types of $\mathrm{Ca}^{2+}$ currents with different sensitivities to organic $\mathrm{Ca}^{2+}$ channel antagonists in guinea pig pancreatic alpha 2 cells. J Gen Physiol 91:243-254

39. Bensal P, Wang Q (2008) Insulin as a physiological modulator of glucagon secretion. Am J Physiol Endocrinol Metab 22 July. doi:10.1152/ajpendo.90295.2008

40. Cabrera O, Jacques-Silva MC, Speier S et al (2008) Glutamate is a positive autocrine signal for glucagon release. Cell Metab 7:545-554

41. Pian P, Bucchi A, Decostanzo A, Robinson RB, Siegelbaum SA (2007) Modulation of cyclic nucleotide-regulated HCN channels by PIP(2) and receptors coupled to phospholipase C. Pflugers Arch 455:125-145 